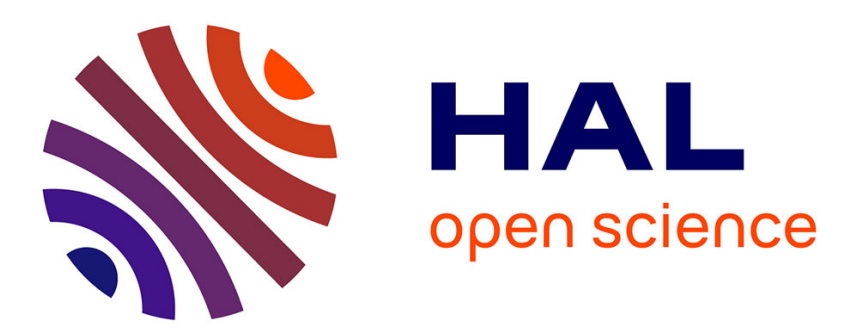

\title{
Capacity of laying hens in sequential feeding to adjust their feed consumption when offered previously a nutritionally unbalanced diet
}

Dolores Batonon, Maxime Traineau, Isabelle Bouvarel, L. Roffidal, Philippe Lescoat

\section{To cite this version:}

Dolores Batonon, Maxime Traineau, Isabelle Bouvarel, L. Roffidal, Philippe Lescoat. Capacity of laying hens in sequential feeding to adjust their feed consumption when offered previously a nutritionally unbalanced diet. European Poultry Science, 2014, 78, 16 p. 10.1399/eps.2014.37 . hal-01198209

\section{HAL Id: hal-01198209 \\ https://hal.science/hal-01198209}

Submitted on 27 May 2020

HAL is a multi-disciplinary open access archive for the deposit and dissemination of scientific research documents, whether they are published or not. The documents may come from teaching and research institutions in France or abroad, or from public or private research centers.
L'archive ouverte pluridisciplinaire HAL, est destinée au dépôt et à la diffusion de documents scientifiques de niveau recherche, publiés ou non, émanant des établissements d'enseignement et de recherche français ou étrangers, des laboratoires publics ou privés. 


\title{
Capacity of laying hens in sequential feeding to adjust their feed consumption when offered previously a nutritionally unbalanced diet
}

\author{
Vermögen von Legehennen, die zuvor mit einer unausgewogenen Ration gefüttert wurden, \\ die Futteraufnahme bei sequentieller Fütterung optimal einzustellen
}

Dolores I. Batonon ${ }^{1,5, *}$, Maxime Traineau ${ }^{1,3,}$, Isabelle Bouvarel $^{2}$, Lucien Roffidal $^{3}$ and Philippe Lescoat $^{1,4}$

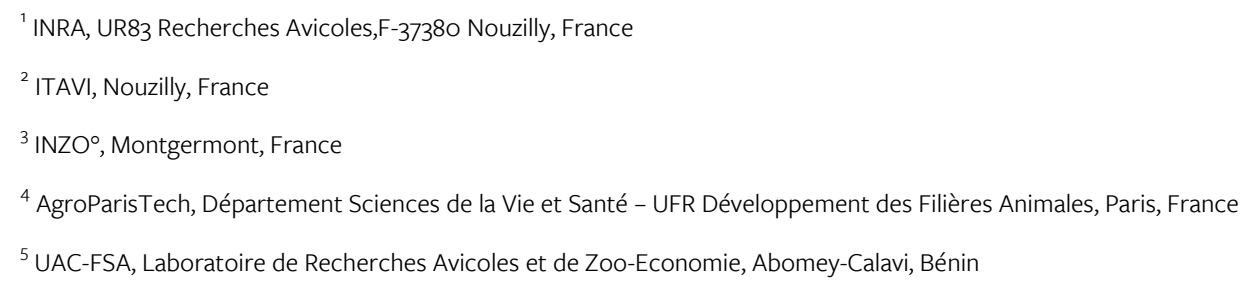

Correspondence: philippe.lescoat@agroparistech.fr

\section{Introduction}

The characteristic of sequential feeding is the offering of two dietary components alternately at different times of the day. This technique was reported as more economical in countries, in which feedstuffs transport and diet mixing are expensive and where the direct use of locally produced feedstuffs could be implemented (UMAR FARUK, 2010). Distribution of a high energy diet in the morning followed by a protein-mineral concentrate in the afternoon resulted in a reduction in feed energy and protein intakes while maintaining egg production, egg weight compared to a complete diet given throughout the day (LEESON and SUMMERS, 1978; REICHMANN and CONNOR, 1979). LEE and OHH (2002) also reported a reduction in feed intake when birds were offered a high energy/protein and low Ca diet in the morning and a low energy/protein and high $\mathrm{Ca}$ in the afternoon.

However, this feeding system impacts birds' weight. Sequentially fed birds were lighter when compared with control fed ones (ROBINSON, 1985; UMAR FARUK et al., 2010a). Low weight could be linked to the lower feed intake, also related to the lower body fat deposition in sequential feeding (SCANES et al., 1987; UMAR FARUK et al., 2011). Since laying performances are assumed to depend on bird's maturity (BOUVAREL et al., 2010; CANET et al., 2012), the question arises whether hens with lower feed intake and lower body weight compared to complete diet are able to go ahead producing at an equivalent level of hens fed complete diet for the whole laying cycle.

Moreover, to the authors' knowledge, there is no specific research on the sensitivity of laying hens to unbalanced diet both in energy and protein under sequential feeding management provided at the beginning of the laying period. Most studies on sequential feeding indicate benefits when birds were offered sequential diets contrasted between morning and afternoon, but with a daily supply similar to the control diets (BLAIR et al., 1973; ROBINSON, 1985; UMAR FARUK et al., 2010a). However, KESHAVARZ (1998) indicated that egg production can't be maintained by providing an adequate level of good quality of protein (16\%) only half a day, compared to the control group that received a diet with $16 \%$ protein the whole day. The flexibility of hens according to the provided nutrients has therefore to be studied. This might help to drive sequentially fed birds to a required shape needed to keep on performing correctly for the whole laying cycle.

Besides, the detrimental effects of high environmental temperature on poultry performance are commonly observed: decreasing egg production (ARIMA et al., 1976), egg mass (DEATON et al., 1986) and egg weight (BALNAVE and BRAKE, 2005). Increasing the dietary level of protein (GUNAWARDANA et al., 2008; ALMEIDA et al., 2012) or allowing bird to consume adequate nutrients before photo-stimulation has been suggested to overcome the negative effect of heat stress (BALNAVE and BRAKE, 2005). Sequential feeding, which maintains egg production in laying hens with a reduction of feed intake under high temperatures, might be a solution in this environment (UMAR FARUK, 2010). 
However, lack of consistent references regarding sequential feeding under high environmental temperatures restrains the flexibility of this system. Consequently, further investigations are required on the ability of laying hens under sequential feeding to control their intakes and performances in contrasted environments.

Therefore, the present work was designed to investigate the direct impacts of sequential distribution of unbalanced diets in energy and protein contents on the performances of laying hens from 20 to 23 weeks-old. A second step was to evaluate the back-effects of 20 to 23 weeks-old unbalanced supplies on performances of laying hens offered balanced sequential feeding between 24 and 29 week-old. To explore contrasted environments, two trials were performed: the first with a neutral temperature and the second with a hot one.

\section{Materials and Methods}

Two different experiments were conducted simultaneously. In both trials, Hendrix Isa Brown laying hens were housed in a three-tier battery having individual cages $(25 \times 38 \mathrm{~cm})$ equipped with a nipple drinker. The feeding through was common to 5 cages. Each group of 5 contiguous cages got the same diet. Birds were offered whole wheat in mixed diet or sequentially from weeks 16 to 18 to implement sequential feeding (UMAR FARUK et al., 2008).

The experimental period ran from week 19 to 30 of age. Photoperiod was 12L:12D at week 16, reached 16L:8D at week 18 and remained at this level until the end of the experiment.

\section{Experimental treatments}

Composition and calculated contents of nutrients of diets are described in Table 1 . The control treatment containing 10.9 MJ/kg and $165 \mathrm{~g} \mathrm{CP} / \mathrm{kg}$ was fed ad libitum and was given in equal portions twice a day between 20 and 29 weeksold. For the sequential combinations, birds received the high-energy fraction $(\mathrm{E})$ in the morning and beginning of the afternoon and the high protein and mineral fraction $(\mathrm{P})$ in the late afternoon and early morning. To test the birds' flexibility, contrasted sequential diets were provided. Energy fraction (E: $98 \mathrm{~g} \mathrm{CP} / \mathrm{kg}, 13.1 \mathrm{MJ} / \mathrm{kg}$ ) and protein fraction (P: $232 \mathrm{~g} \mathrm{CP} / \mathrm{kg}, 8.8 \mathrm{MJ} / \mathrm{kg}$ ) were offered in varying proportions: $50 \mathrm{~g}$ of E between 8:45 h and 14:45 h and $75 \mathrm{~g}$ P between 14:45 $\mathrm{h}$ and 8:45 $\mathrm{h}$ for the E40/P60 diet; $62.5 \mathrm{~g}$ of E between 8:45 $\mathrm{h}$ and 15:45 $\mathrm{h}$ and $62.5 \mathrm{~g}$ of $\mathrm{P}$ between 15:45 $\mathrm{h}$ and 8:45 $\mathrm{h}$ for the E50/P50 diet; $75 \mathrm{~g}$ of E between 8:45 h and 16:45 $\mathrm{h}$ and $50 \mathrm{~g}$ of P between 16:45 $\mathrm{h}$ and 8:45 h for E60/P40. Each bird was offered $125 \mathrm{~g}$ of feed i.e. 105\% of the theoretical requirement of laying hens (ISA, 2011). 
Table 1. Composition of experimental diets given to laying hens between 19 and 29 weeks-old

Zusammensetzung der Versuchsrationen für die Legehennen im Altersabschnitt 19, bis 29. Lebenswoche

\begin{tabular}{|c|c|c|c|}
\hline Ingredient $(\mathrm{g} / \mathrm{kg})$ & Control diet & Energy fraction (E) & Protein fraction (P) \\
\hline Corn & 444.5 & 715.0 & 170.0 \\
\hline Wheat & 160.0 & - & 125.0 \\
\hline Wholewheat & - & 200.0 & - \\
\hline Soybeanmeal & 200.0 & - & 399.0 \\
\hline Calcium carbonate & 75.9 & & 149.5 \\
\hline Sunflowermeal & 78.0 & 69.0 & 87.0 \\
\hline Soybeanoil & 16.0 & 16.0 & 17.0 \\
\hline Dicalcium phosphate & 13.1 & - & 2.7 \\
\hline Premix ${ }^{1}$ & 10.0 & - & 20.0 \\
\hline DL-Methionine & 1.6 & - & 3.4 \\
\hline L-Lysine & 0.1 & - & 0.2 \\
\hline \multicolumn{4}{|c|}{ Calculated composition $(g / k g)$} \\
\hline $\operatorname{ME}(\mathrm{MJ} / \mathrm{kg})^{2}$ & 10.9 & 13.1 & 8.8 \\
\hline $\mathrm{CP}$ & 165.0 & 98.0 & 231.7 \\
\hline Analyzed CP (g/kg) & 170.2 & 99.1 & 231.7 \\
\hline DM & 886.5 & 871.9 & 901.4 \\
\hline Calcium & 36.0 & 0.4 & 71.0 \\
\hline Fat & 40.2 & 46.8 & 34.5 \\
\hline Total P & 5.9 & 2.9 & 9.0 \\
\hline Available P & 3.1 & 0.7 & 5.7 \\
\hline Lysine & 8.2 & 3.2 & 13.2 \\
\hline Methionine & 4.5 & 2.1 & 7.1 \\
\hline Threonine & 6.6 & 3.6 & 9.4 \\
\hline Tryptophan & 2.0 & 0.9 & 3.0 \\
\hline
\end{tabular}

\footnotetext{
'Premix: Supplied per kg of diet at Vitamin A 750000 UI, Vitamin D3 300000 UI, Vitamin E (tocopherolacetate za700) 1000 UI, Vitamin K3 100 mg, Zinc $10000 \mathrm{mg}$, Manganese $10000 \mathrm{mg}$, Copper $1000 \mathrm{mg}$, Iron $4000 \mathrm{mg}$, lode $150.0 \mathrm{mg}$, Selenium 30.0 mg; Canthaxanthin 1950.0 mg, ß-apocarotenoïcacid $2000.0 \mathrm{mg}$, lutein $3560.0 \mathrm{mg}$, zeaxanthin $200.0 \mathrm{mg}$, Cryptoxanthin $80.0 \mathrm{mg}$, Citricacid $400.00 \mathrm{mg}$, orthophosphoricacid $660.00 \mathrm{mg}$, Ethoxyquin $400 \mathrm{mg}$, Propyl gallate (E310) $400 \mathrm{mg}$.

${ }^{2}$ Nutritional values were calculated by INZO adapted from SAUVANT et al., 2004
}

Since corn is richer in energy and lower in protein than wheat (SAUVANT et al., 2004), the energy fraction was formulated mostly with ground corn and a limited amount of $20 \%$ whole wheat to obtain large differences of nutrient supply dynamics between experimental diets. Inclusion of whole grains in the diet of laying hens was chosen to stimulate the digestive capacity of hens (NIR et al., 1990) by increasing the gizzard size. Hens with E40/P60 received $10.5 \mathrm{MJ} \mathrm{ME} / \mathrm{kg}$ and $178 \mathrm{~g} \mathrm{CP} / \mathrm{kg}$, hens with E50/P50 received $10.9 \mathrm{MJ} \mathrm{ME} / \mathrm{kg}$ and $165 \mathrm{~g} \mathrm{CP} / \mathrm{kg}$ and those in E60/P40 group received $11.4 \mathrm{MJ} \mathrm{ME} / \mathrm{kg}$ and $152 \mathrm{~g} \mathrm{CP} / \mathrm{kg}$. Diets were formulated according to INRA tables (SAUVANT et al., 2004). Water was given ad libitum throughout the experimental period.

\section{Experiment 1 (Exp. 1)}

The objective of this experiment was to evaluate the impacts of unbalanced diets in energy and protein contents offered sequentially on the performances of laying hens from 20 to 23 weeks old in neutral environmental condition. Experimental design is described Table 2. One hundred and twenty birds were reared at $20.4^{\circ} \mathrm{C} \pm 0.02$, kept constant from week 19 to week 30 . Birds were divided into 4 groups of 30 birds ( 6 feeding troughs $* 5$ contiguous cages). Four different diets were provided in this experiment between 20 and 23 weeks: control diet and 3 sequential diets $(40 \mathrm{E} / 60 \mathrm{P} ; 50 \mathrm{E} / 50 \mathrm{P} ; 60 \mathrm{E} / 40 \mathrm{P})$. To investigate the ability of laying hens receiving contrasted diets from 20 to 23 weekold, to converge on similar characteristics at 30 weeks of age, two diets were given between week 24 and 29: the control one to the birds receiving earlier the same diet and the 50E/50P to all other birds. 


\begin{tabular}{lcc}
\hline & Control & Control \\
Diets & E40/P60 & E50/P50 \\
& E60/P50 & 6 \\
Replicates (group of 5 hens) & 60 \\
Number of birds & 30 \\
\hline
\end{tabular}

A Control diet was fed ad libitum between 20 and 29 weeks-old. Between 20 and 23 weeks-old, 3 sequential diets were provided in the morning for $E$ and in mid-afternoon for P: E40/P60: $50 \mathrm{~g}$ of the energy fraction (E) and $75 \mathrm{~g}$ of protein fraction (P); E50/P50: $62.5 \mathrm{~g}$ of E and 62.5 g of P; E60/P40: $75 \mathrm{~g}$ of E and 50 g of P.Between 24 and 29 weeks of age, birds previously with E40/P60, E50/P50 or E60/P40 were offered the same sequential diet, E50/P50.

\section{Experiment 2 (Exp. 2)}

A group of 60 hens was placed in a constantly hot temperature room $\left(25.8^{\circ} \mathrm{C} \pm 0.02^{\circ} \mathrm{C}\right)$ to study the impacts of sequential distribution of unbalanced diets from 20 to 23 weeks on bird's response in this environment. As in the first experiment (Table 2), birds were divided into 3 groups of 20 birds ( 4 feeding troughs * 5 contiguous cages). They were habituated to this high temperature by a gradual increase to avoid acute heat stress (DANIEL and BALNAVE, 1981; EMERY et al., 1984). An excessive energy supply as provided by 60E/40P could dramatically decrease the overall feed intake and this diet was therefore omitted. Thus, control diet and 2 sequential diets (40E/60P; 50E/50P) were provided between 20 and 23 weeks. In the second period, birds got two diets: the control one and the 50E/50P, as in the first experiment.

\section{Measurements}

Feed intake was recorded weekly for each group of five cages. In the sequentially fed treatments, intakes of $E$ and $P$ were measured separately. Egg production was measured by recording the number of eggs produced daily. Egg weight was recorded four times a week. Weight of egg components (yolk, albumen, shell) was determined on a daily sample every 3 weeks, starting at week 21 . Albumen and the chalazae were separated using forceps prior to weighing the yolk. Shells were washed and dried for 12 hours in a drying oven at $70^{\circ} \mathrm{C}$ and then weighed.

Birds were weighed individually at 16, 19, 23 and 30 weeks of age. Body composition was predicted with a noninvasive method based on Bioelectrical Impedance Analysis (BIA) at week 19, 23 and 30. The technique has been developed by the company INZO ${ }^{\circ}$. It is assumed that the electrical impedance of the biological organism is indicative of the highly conductive fat-free component (BERG and MARCHELLO, 1994). The electrical impedance of a tissue depends on its fluid and electrolyte content (RUTTER et al., 1998) and therefore on their relative proportions of muscle, lipid, water and ash. Considering that, these proportions could consequently be predicted. This method allows monitoring the evolution of the body composition throughout the experimental period.

The weight of the digestive organs was recorded at the end of the trials to assess the effect of feeding system and temperature conditions. For both experiments, ten birds per treatment randomly selected were weighed before being injected with sodium Pentobarbital solution ( $1 \mathrm{ml} / \mathrm{kg}$ body weight). The abdominal cavity was opened, the digestive tract dissected and separated into gizzard, small intestine, pancreas, liver and spleen. Gizzard was placed into an iced container $\left(-4^{\circ} \mathrm{C}\right)$ for $24 \mathrm{~h}$ to facilitate the removal of the surrounding fat before being emptied and weighed.

\section{Statistical analysis}

Data from each experiment were analyzed based on 2 periods: from 20 to 23 weeks of age and from 24 to 29 weeks of age, according to the changing of diets at 24 weeks of age. The experimental unit for feed consumption (feed intake, fractional intakes, $\mathrm{ME}$ and $\mathrm{CP}$ intakes) and feed conversion ratio was the group of 5 contiguous cages due to the common feeding trough. The analyses on the other variables were based on individual values from cages. 
In Exp. 1, control diet was compared to all sequential diets; then, the effects between the three sequential diets (E40/P60 vs. E50/P50 vs. E60/P40) were tested. A one-way ANOVA was performed to test the treatment effect on all measured variables. Results were considered significantly different if $\mathrm{P}<0.05$, and a Bonferroni-Dunnet pairwise comparison was used to compare differences between means.

In hot environmental condition (Exp. 2), only the diet effect was tested (Control vs. E40/P60 vs. E50/P50). Due to the number of replications in this experiment, non-parametric tests were performed on feed consumption data and on feed conversion ratio. When there are only two groups ( $\mathrm{E}$ and $\mathrm{P}$ fractions intake), a Mann-Whitney test was performed and Kruskal-Wallis test was realized for comparison of the 3diets (total feed intake, ME, CP intake and FCR). Laying performances and digestive organs weights have been submitted to a one-way ANOVA. Similarly, results were considered significantly different if $\mathrm{P}<0.05$, and Bonferroni-Dunnet pairwise comparison was used to compare differences between means.

Body content was submitted to a one-way repeated measures ANOVA. Statistical analyses were performed using $R$ version 2.15.2 (R CORE TEAM, 2012).

\section{Results}

Effect of the feeding systems in the neutral temperature condition (Exp. 1)

Weeks 20 to 23. From 20 to 23 weeks of age, no difference was observed with E40/P60, E50/P50 and E60/P40 compared to control diet for total feed, ME and CP intakes (Table 3). In sequential feeding, energy and protein contents did not affect the total feed intake. However, energy fraction (E) intake was significantly lower with E40/P60 diet compared to the two other sequential diets, representing respectively about $42 \%, 51 \%$ and $59 \%$ of the total feed intake. Regarding protein fraction (P) intake, the complementary results were observed. ME intake was similar among the treatments while CP intake was significantly affected by sequential diets. The pairwise comparison showed that E50/P50 protein intake tended to be different from the E60/P40 whereas both diets are significantly lower than the E40/P60. Egg production was increased with the sequential diets compared to the control one. Egg weight, egg mass and egg components proportions were similar between control and sequential diets except for the egg shell percentage. Feed conversion ratios (FCR) were higher with control group (2.20) compared to sequential ones (2.04). There was no difference in feed efficiency within the sequential diets. 
Table 3. Effect of feeding systems between week 20 and 23 of life on performances of laying hens between 20 and 29 weeks-old in neutral temperature condition (Experiment 1)

Einfluss des Fütterungssystems zwischen der 20. und 23. Lebenswoche auf die Leistung der Legehennen im Altersabschnitt 20. bis 29. Lebenswoche unter neutralen Temperaturbedingungen (Versuch 1)

\begin{tabular}{|c|c|c|c|c|c|c|c|}
\hline & $\begin{array}{c}\text { Control } \\
\text { diet }^{1}\end{array}$ & E40/P6o & E50/P50 & E6o/P40 & SEM & $\begin{array}{l}\text { Control vs. } \\
\text { Sequential }^{2}\end{array}$ & $\begin{array}{l}\text { E40/P60 vs. } \\
\text { E50/P50 vs. } \\
\text { E60/P40 }\end{array}$ \\
\hline$N^{3}$ & $(N=6)$ & $(N=6)$ & $(N=6)$ & $(N=6)$ & & & \\
\hline \multicolumn{8}{|c|}{ Total feed intake (g/b/d) } \\
\hline Wk2O-23 & 107 & 107 & 104 & 103 & 1.55 & NS & NS \\
\hline Wk24-29 & 119 & 117 & 115 & 115 & 1.60 & $<0.10$ & NS \\
\hline \multicolumn{8}{|c|}{ Energy fraction intake $(\mathrm{g} / \mathrm{b} / \mathrm{d})$} \\
\hline Wk2O-23 & & $44.8^{a}$ & $53 \cdot 3^{b}$ & $60.3^{c}$ & 0.87 & & $<0.01$ \\
\hline Wk24-29 & & 56.6 & 55.6 & $55 \cdot 3$ & 1.30 & & NS \\
\hline \multicolumn{8}{|c|}{ Protein fraction intake $(\mathrm{g} / \mathrm{b} / \mathrm{d})$} \\
\hline Wk2O-23 & & $60.9^{a}$ & $50.4^{b}$ & $42.4^{c}$ & 1.18 & & $<0.01$ \\
\hline Wk24-29 & & 59.8 & 59.5 & 59.9 & 0.41 & & NS \\
\hline \multicolumn{8}{|c|}{ ME intake (MJ/b/d) } \\
\hline Wk2O-23 & 1.24 & 1.19 & 1.21 & 1.23 & 0.02 & NS & NS \\
\hline Wk24-29 & 1.38 & 1.35 & 1.33 & 1.33 & 0.02 & $<0.10$ & NS \\
\hline \multicolumn{8}{|c|}{ CP intake $(g / b / d)$} \\
\hline Wk2O-23 & 18.4 & $19.4^{\mathrm{a}}$ & $17.7^{\mathrm{B}}$ & $16.4^{\mathrm{C}}$ & 0.29 & NS & $<0.01$ \\
\hline Wk24-29 & 20.5 & 20.3 & 20.1 & 20.2 & 0.22 & NS & NS \\
\hline \multicolumn{8}{|c|}{ Feed conversion ratio } \\
\hline Wk2O-23 & 2.20 & 2.02 & 2.09 & 1.99 & 0.06 & $<0.05$ & NS \\
\hline Wk24-29 & 2.05 & 1.98 & 1.91 & 1.90 & 0.05 & NS & NS \\
\hline$N^{4}$ & $(N=30)$ & $(N=30)$ & $(N=30)$ & $(N=29)$ & & & \\
\hline \multicolumn{8}{|c|}{ Egg production (\%) } \\
\hline Wk2O-23 & 82.0 & 91.2 & 88.7 & 93.0 & 2.92 & $<0.05$ & NS \\
\hline Wk24-29 & 92.4 & 97.7 & 96.6 & 98.8 & 1.48 & $<0.05$ & NS \\
\hline \multicolumn{8}{|c|}{ Egg weight (g) } \\
\hline Wk2O-23 & 56.9 & 56.8 & 55.9 & 55.1 & 0.67 & NS & NS \\
\hline Wk24-29 & 62.6 & 61.7 & 62.3 & 61.3 & 0.89 & NS & NS \\
\hline \multicolumn{8}{|c|}{ Egg mass (g/b/d) } \\
\hline Wk2O-23 & 48.6 & 52.0 & 49.7 & 51.2 & 1.75 & NS & NS \\
\hline Wk24-29 & 58.9 & 59.1 & 60.2 & 60.6 & 1.54 & NS & NS \\
\hline \multicolumn{8}{|c|}{ Egg yolk (\%) } \\
\hline Wk2O-23 & 21.6 & 21.7 & 21.4 & 22.0 & 0.32 & NS & NS \\
\hline Wk24-29 & 23.7 & 23.8 & 23.6 & 23.9 & 0.34 & NS & NS \\
\hline \multicolumn{8}{|c|}{ Egg albumen (\%) } \\
\hline Wk2O-23 & 68.0 & 68.0 & 68.7 & 68.0 & 0.40 & NS & NS \\
\hline Wk24-29 & 66.1 & 65.8 & 65.9 & 65.5 & 0.38 & NS & NS \\
\hline \multicolumn{8}{|c|}{ Egg shell (\%) } \\
\hline Wk2O-23 & 10.44 & $10.30^{B}$ & $9.82^{C}$ & $9.96^{\mathrm{BC}}$ & 0.15 & $<0.05$ & $<0.10$ \\
\hline Wk24-29 & 10.13 & 10.42 & 10.40 & 10.62 & 0.12 & $<0.05$ & NS \\
\hline \multicolumn{8}{|c|}{ Body weight (g) } \\
\hline Wk 19 & 1571 & 1569 & 1579 & 1610 & 22.23 & NS & NS \\
\hline Wk 23 & 1736 & 1644 & 1624 & 1646 & 24.50 & $<0.01$ & NS \\
\hline Wk 30 & 1813 & 1669 & 1650 & 1658 & 25.53 & $<0.01$ & NS \\
\hline
\end{tabular}

${ }^{1}$ A Control diet was fed ad libitum between 20 and 29 weeks-old. Between 20 and 23 weeks-old, 3 sequential diets were provided in the morning for $E$ and in mid-afternoon for P: E4O/P60: $50 \mathrm{~g}$ of the energy fraction (E) and $75 \mathrm{~g}$ of protein fraction (P); E5O/P5O: $62.5 \mathrm{~g}$ of $\mathrm{E}$ and $62.5 \mathrm{~g}$ of P; E60/P40: $75 \mathrm{~g}$ of $\mathrm{E}$ and $50 \mathrm{~g}$ of P.Between 24 and 29 weeks of age, birds previously with E40/P60, E50/P50 or E60/P40 were offered the same sequential diet, E50/P50.

${ }^{2}$ Probability mentioned matches the effect of control diet vs. all sequential diets.

${ }^{3}$ The experimental unit for the feed ad nutrient consumption and feed conversion ratio was the group of 5 contiguous cages $(\mathrm{N}=6)$ due to the common feeding trough.

${ }^{4}$ The analysis was based on individual values from cages. One bird's mortality was recorded in the E60/P40 diet.

${ }^{\mathrm{a}, \mathrm{b}, \mathrm{c}}$ : values within the same row not sharing a common superscript letter differ significantly at $P<0.05 .^{\mathrm{A}, \mathrm{B}, \mathrm{C}}$ : have a trend at $P<0.10$, not significantly at $P>0.10$ 
Weeks 24 - 29. From weeks 24 to 29, total feed intake tended to be higher for the control than for the sequential diets $(\mathrm{P}<0.10)$ with no difference between sequential diets (Table 3$)$. All sequentially fed hens ate a similar quantity of $\mathrm{E}$ (around $48 \%$ of total feed intake) and $\mathrm{P}$ (around $52 \%$ of total feed intake). Layers with control diet tended to eat more ME than hens with sequential diets $(\mathrm{P}<0.10)$ whereas $\mathrm{CP}$ intake was similar among all treatments. As previously observed, egg production was significantly increased with the three sequential groups compared to the control one. Egg weight, egg mass, egg yolk and albumen proportion did not present any difference among all diets. Egg shell percentage was found to be lower in the control compared to the 3 sequential groups. FCR were similar between the four groups from weeks 24 to 29 of age.

Body weights were similar at week 19 for all diets and they increased with age. Hens fed sequentially were always significantly lighter than control fed ones. The average body weight values were $1736 \mathrm{~g}$ for hens with control diet and $1638 \mathrm{~g}$ for hens with sequential diets at week 23. At week 30, they were $1813 \mathrm{~g}$ and $1659 \mathrm{~g}$, respectively, for the control and the sequential ones.

At 30 weeks-of-age, pancreas, liver and spleen proportions were not influenced by the feeding system (Table 5). Nevertheless, sequential feeding resulted in significantly heavier gizzard relative to control diet. No difference in the proportion of small intestine was recorded between all treatments except for E40/P60 diet, which tended to be higher thanE50/P50. The heaviest abdominal fat proportion was obtained with control group, whereas the lowest was obtained with E40/P60. Figures $1 \mathrm{a}$ and $1 \mathrm{~b}$ show the time change in fat and protein contents according to diets from 19 to 30 weeks of age. There was a significant increase in fat level in all treatments with age, although hens fed sequentially had significantly lower fat content. Birds in sequential feeding had similar fat content. Hens fed with sequential diets were significantly higher than the control ones regarding protein proportion while no difference was observed within sequential diets.

Table 5. Effects of feeding systems between week 20 and 23 of life on weight of digestive organs and abdominal fat at 30 weeks of age (experiments 1 and 2)

Einfluss des Fütterungssystems zwischen der 20. und 23. Lebenswoche auf das Gewicht der Verdauungsorgane und das Abdominalfett in der 30. Lebenswoche (Versuche 1 und 2)

\begin{tabular}{|c|c|c|c|c|c|c|c|}
\hline$\%$ BW & & Gizzard & $\begin{array}{c}\text { Small } \\
\text { intestine }\end{array}$ & Pancreas & Liver & Spleen & Abdominal fat \\
\hline \multicolumn{8}{|l|}{ Experiment 1} \\
\hline Control diet & $N=10$ & 1.45 & 1.95 & 0.19 & 2.91 & 0.085 & 2.7 \\
\hline E40/P6o & $N=10$ & 1.66 & $2.15^{\mathrm{AB}}$ & 0.20 & 2.81 & 0.084 & 1.4 \\
\hline $\mathrm{E}_{50} / \mathrm{P}_{50}$ & $N=10$ & 1.63 & $1.95^{\mathrm{A}}$ & 0.20 & 2.89 & 0.093 & 1.4 \\
\hline $\mathrm{E} 60 / \mathrm{P} 40$ & $N=10$ & 1.63 & $2.18^{\mathrm{B}}$ & 0.21 & 2.79 & 0.091 & 1.9 \\
\hline Control vs. Sequential* & & $<0.01$ & NS & NS & NS & NS & $<0.01$ \\
\hline E40/P60 vs. E50/P50 vs. E60/P40 & & NS & $<0.10$ & NS & NS & NS & NS \\
\hline \multicolumn{8}{|l|}{ Experiment 2} \\
\hline Control diet & $N=10$ & 1.45 & $1.70^{a}$ & $0.19^{A}$ & 2.68 & 0.100 & $3.1^{\mathrm{a}}$ \\
\hline E40/P6o & $N=10$ & 1.67 & $1.89^{b}$ & $0.20^{A B}$ & 2.80 & 0.077 & $1.3^{b}$ \\
\hline $\mathrm{E}_{5} \mathrm{O} / \mathrm{P}_{50}$ & $N=10$ & 1.55 & $1.88^{\mathrm{ab}}$ & $0.2^{B}$ & 2.82 & 0.103 & $1.7^{\mathrm{b}}$ \\
\hline SEM & & 0.07 & 0.06 & 0.006 & 0.11 & 0.007 & 0.28 \\
\hline Control vs. E40/P6o vs. E50/P50 & & NS & $<0.05$ & $<0.10$ & NS & $<0.10$ & $<0.01$ \\
\hline
\end{tabular}

A Control diet was fed ad libitum between 20 and 29 weeks-old. Between 20 and 23 weeks-old, 3 sequential diets were provided in the morning for $\mathrm{E}$ and in mid-afternoon for P: E4O/P60: $50 \mathrm{~g}$ of the energy fraction (E) and $75 \mathrm{~g}$ of protein fraction (P) E50/P50: 62.5 g of (E)and 62.5 g of (P); E60/P40: $75 \mathrm{~g}$ of (E) and $50 \mathrm{~g}$ of $(\mathrm{P})$. Between 24 and 29 weeks of age, birds previously with E40/P60, E50/P50 or E60/P40 were offered the same sequential diet: $\mathrm{E}_{50} \mathrm{O} / \mathrm{P}_{50}$.

* Probability mentioned matches the effect of control diet vs. all sequential diets.

${ }_{\mathrm{a}, \mathrm{b}, \mathrm{c}}$ : values within the same column not sharing a common letter differ significantly at $P<0.05$, NS, not significantly at $P>0.10$. 


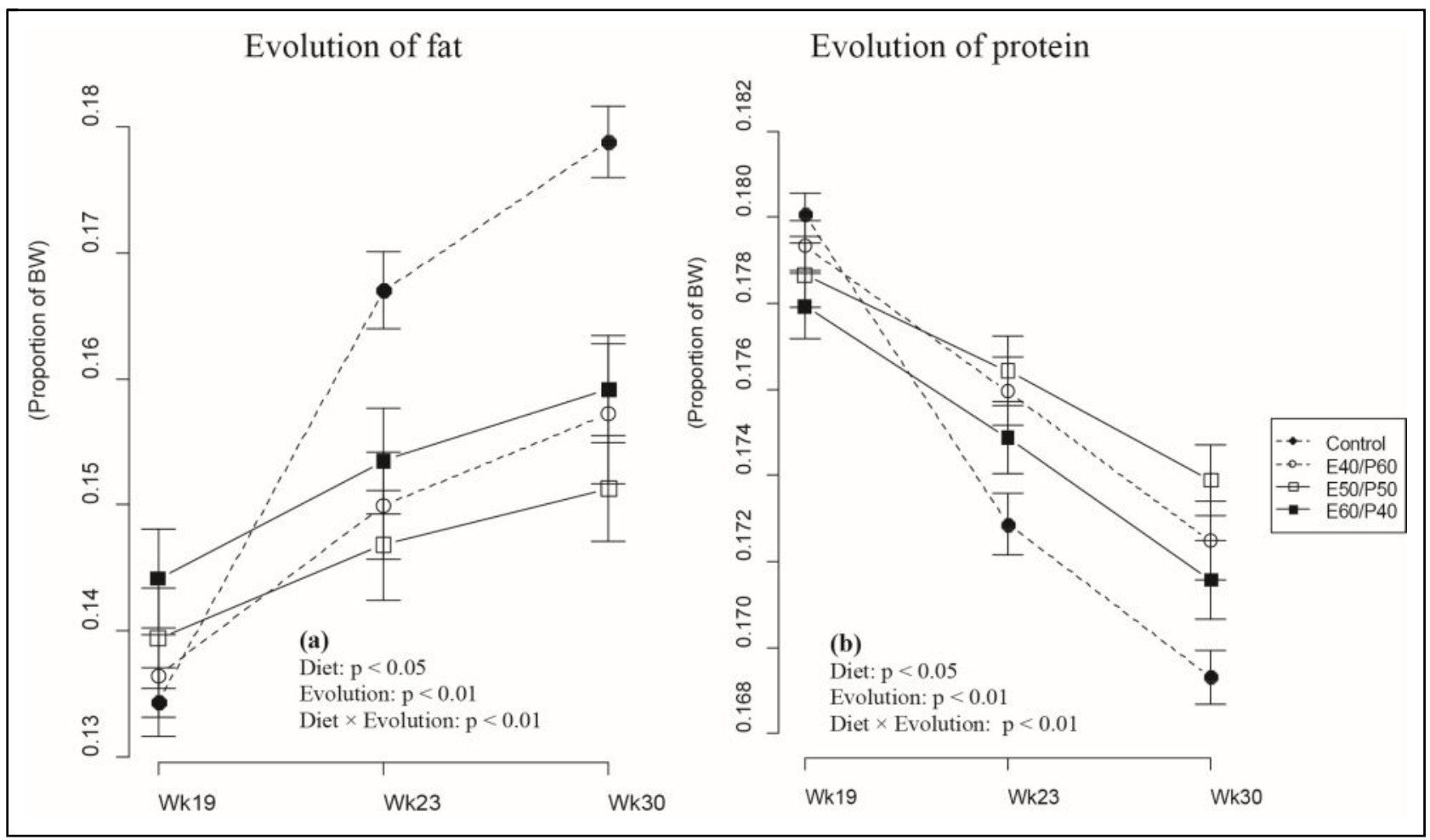

Figure 1. Effects of feeding systems between week 20 and 23 of life on estimated body composition (protein proportion and fat proportion) at 19, 23 and 30 weeks-old for laying hens fed between 19 and 30 weeks of age with control or a sequential combination of energy and protein fractions (Exp. 1)

Einfluss des Fütterungssystems zwischen der 20. und 23. Lebenswoche auf die geschätzte Körperzusammensetzung (Protein- und Fettanteil) von Legehennen, die zwischen der 19. und 30. Lebenswoche mit einem Kontrollfutterregime oder einer sequentiellen Kombination von Energie- und Proteinfraktionen gefüttert wurden, in der 19., 23. und 30. Lebenswoche (Versuch 1)

Hens in sequential groups got similar performances at 23 weeks old but they were significantly different from the control group regarding feed efficiency. The results obtained from 24 to 29 weeks-of-age indicated that birds with different feed consumption at 23 week-old converged to the same level of intake when they were given access to the same diet. Laying performances and body content did not vary within the sequential group with the change of diets.

\section{Effect of feeding systems on laying hens performances under high temperature (Exp. 2)}

Weeks 20 to 23. Total feed intake during the distribution of unbalanced diets (Table 4) tended to be affected by feeding system: it tended to be lower for E40/P60 than the control while E40/P60 was similar to E50/P50. Birds fed E50/P50 diet consumed more E (around 47\% of total feed intake) than birds in E40/P60 (around 41\% of total feed intake) whereas no difference was observed for $\mathrm{P}$ intake. ME intake was significantly reduced with E40/P60 diet compared to E50/P50 and Control while CP intake was similar among treatments. 
Table 4. Effect of feeding systems between week 20 and 23 of life on performances of laying hens between 20 and 29 weeks-old under hot condition (Experiment 2)

Einfluss des Fütterungssystems zwischen der 20. und 23. Lebenswoche auf die Leistung der Legehennen im Altersabschnitt 20. bis 29. Lebenswoche unter heißen Temperaturbedingungen (Versuch 2)

\begin{tabular}{|c|c|c|c|c|c|}
\hline & Control diet ${ }^{1}$ & E40/P6o & $E_{50 / P 50}$ & SEM & $\begin{array}{c}\text { Control vs. } \\
\text { E40/P60 vs. } \\
\text { E50/P50 }\end{array}$ \\
\hline$N^{2}$ & $(N=4)$ & $(N=4)$ & $(N=4)$ & & \\
\hline \multicolumn{6}{|c|}{ Total feed intake (g/b/d) } \\
\hline Wk2O-23 & 104 & 96.8 & 98.8 & 1.92 & $<0.10$ \\
\hline Wk24-29 & 112 & 107 & 109 & 1.62 & NS \\
\hline \multicolumn{6}{|c|}{ Energy fraction intake $(\mathrm{g} / \mathrm{b} / \mathrm{d})$} \\
\hline Wk2O-23 & & 39.7 & 46.6 & 0.93 & $<0.01$ \\
\hline Wk24-29 & & 48.2 & 49.4 & 0.81 & NS \\
\hline \multicolumn{6}{|c|}{ Protein fraction intake (g/b/d) } \\
\hline Wk2O-23 & & 57.0 & 52.1 & 1.47 & NS \\
\hline Wk24-29 & & 57.1 & 59.2 & 0.69 & $<0.05$ \\
\hline \multicolumn{6}{|c|}{ ME intake $(\mathrm{MJ} / \mathrm{b} / \mathrm{d})$} \\
\hline Wk2O-23 & $1.20^{\mathrm{a}}$ & $1.09^{b}$ & $1.14^{a b}$ & 0.02 & $<0.05$ \\
\hline Wk24-29 & 1.19 & 1.12 & 1.20 & 0.07 & NS \\
\hline \multicolumn{6}{|c|}{ CP intake $(g / b / d)$} \\
\hline Wk2O-23 & 17.9 & 17.9 & 17.4 & 0.37 & NS \\
\hline Wk24-29 & 17.7 & 17.6 & 18.8 & 1.01 & NS \\
\hline \multicolumn{6}{|c|}{ Feed conversion ratio } \\
\hline Wk2O-23 & 1.95 & 1.82 & 1.87 & 0.07 & NS \\
\hline Wk24-29 & 1.94 & 1.93 & 1.90 & 0.06 & NS \\
\hline$N^{3}$ & $(N=20)$ & $(N=20)$ & $(N=20)$ & & \\
\hline \multicolumn{6}{|c|}{ Egg production (\%) } \\
\hline Wk2O-23 & 96.4 & 94.5 & 96.1 & 2.13 & NS \\
\hline Wk24-29 & 95.1 & 92.4 & 96.3 & 1.27 & NS \\
\hline \multicolumn{6}{|c|}{ Egg weight (g) } \\
\hline Wk2O-23 & 56.3 & 55.6 & 54.7 & 0.85 & NS \\
\hline Wk24-29 & 61.3 & 60.3 & 59.3 & 0.87 & NS \\
\hline \multicolumn{6}{|c|}{ Egg mass (g/b/d) } \\
\hline Wk2O-23 & 54.4 & 52.7 & 52.8 & 1.61 & NS \\
\hline Wk24-29 & 58.3 & 55.8 & 57.2 & 1.32 & NS \\
\hline \multicolumn{6}{|c|}{ Egg yolk (\%) } \\
\hline Wk2O-23 & 21.9 & 21.6 & 21.0 & 0.31 & NS \\
\hline Wk24-29 & 23.4 & 22.7 & 22.6 & 0.34 & NS \\
\hline \multicolumn{6}{|c|}{ Egg albumen (\%) } \\
\hline Wk2O-23 & $68.2^{\mathrm{a}}$ & $68.7^{a b}$ & $69.4^{b}$ & 0.34 & $<0.05$ \\
\hline Wk24-29 & 66.8 & 67.3 & 67.0 & 0.37 & NS \\
\hline \multicolumn{6}{|c|}{ Egg shell (\%) } \\
\hline Wk2O-23 & 9.9 & 9.7 & 9.6 & 0.17 & NS \\
\hline Wk24-29 & $9.8^{\mathrm{A}}$ & $10.1^{A B}$ & $10.3^{B}$ & 0.14 & $<0.10$ \\
\hline \multicolumn{6}{|c|}{ Body weight (g) } \\
\hline Wk 19 & 1565 & 1575 & 1590 & 22.19 & NS \\
\hline Wk 23 & $1652^{a}$ & $1550^{b}$ & $1577^{\mathrm{ab}}$ & 25.78 & $<0.05$ \\
\hline Wk 30 & $1701^{a}$ & $1571^{b}$ & $1624^{a b}$ & 28.89 & $<0.01$ \\
\hline
\end{tabular}

${ }^{1}$ A Control diet was fed ad libitum between 20 and 29 weeks-old. Between 20 and 23 weeks-old, 3 sequential diets were provided in the morning for $E$ and in mid-afternoon for P: E40/P60: $50 \mathrm{~g}$ of the energy fraction (E) and $75 \mathrm{~g}$ of protein fraction (P) E50/P50: 62.5 g of (E)and 62.5 g of (P); E60/P4O: $75 \mathrm{~g}$ of (E) and $50 \mathrm{~g}$ of $(\mathrm{P})$. Between 24 and 29 weeks of age, birds previously with E40/P60, E50/P50 or E60/P40 were offered the same sequential diet: E50/P50.

${ }^{2}$ The experimental unit for the feed consumption and feed conversion ratio was the group of 5 contiguous cages $(N=4)$ due to the common feed trough.

${ }^{3}$ Analysis was based on individual values from cages.

${ }^{\mathrm{a}, \mathrm{b}, \mathrm{c}}$ : values within the same row not sharing a common superscript letter differ significantly at $P<0.05{ }^{\mathrm{A}, \mathrm{B}, \mathrm{C}}$ : have a trend at $P<0.10$, not significantly at $P>0.10$. 
Besides, there was no effect of the feeding systems on FCR and laying performances. The only meaningful difference in terms of egg components weights was observed with egg albumen proportion, significantly lower in control diet compared to the two sequential ones.

Hens have a similar body weight at week 19 which increased with age. Sequential feeding reduced body weight, the lower value was recorded for E40/P60 diet at week 23.

Weeks 24 to 29. Feeding systems did not affect total feed intake, E fraction intake, ME and CP intake, from weeks 24 to 29 (Table 4). The only difference was observed for $\mathrm{P}$ fraction intake with the highest consumption in E50/P50 compared to E40/P60. Moreover, there is no diet effect on laying performances. Egg weight and egg mass increased with age and there was no difference between control and sequentially fed birds. Egg albumen tended to be different according to the diet effect at $\mathrm{P}<0.10$ while no difference was found for egg yolk and egg shell proportions. Birds had similar feed conversion ratio: 1.94, 1.93 and 1.90 respectively for the control, E40P60 and E50/P50 diets. Body weight increased with age and hens inE40/P60 group were lighter than those in control diet at week 30.

No significant difference was observed in gizzard weight between all diets (Table 5). However, hens fed with control diet have a lighter small intestine than those fed E40/P60. Pancreas weight tended to be lower for hens with control diet compared to E50/P50 diet, whereas, spleen weight tended to be lower for E40/P60 than for the others two diets $(\mathrm{P}<0.10)$. The heaviest abdominal fat weight was obtained with Control.

Figures $2 \mathrm{a}$ and $2 \mathrm{~b}$ show achange in fat and protein contents from 19 to 30 weeks of age. There was a significant increase in fat level in all treatments with time with no difference between diets. As previously observed, protein contents decreased with age but they were similar between sequential diets and control.

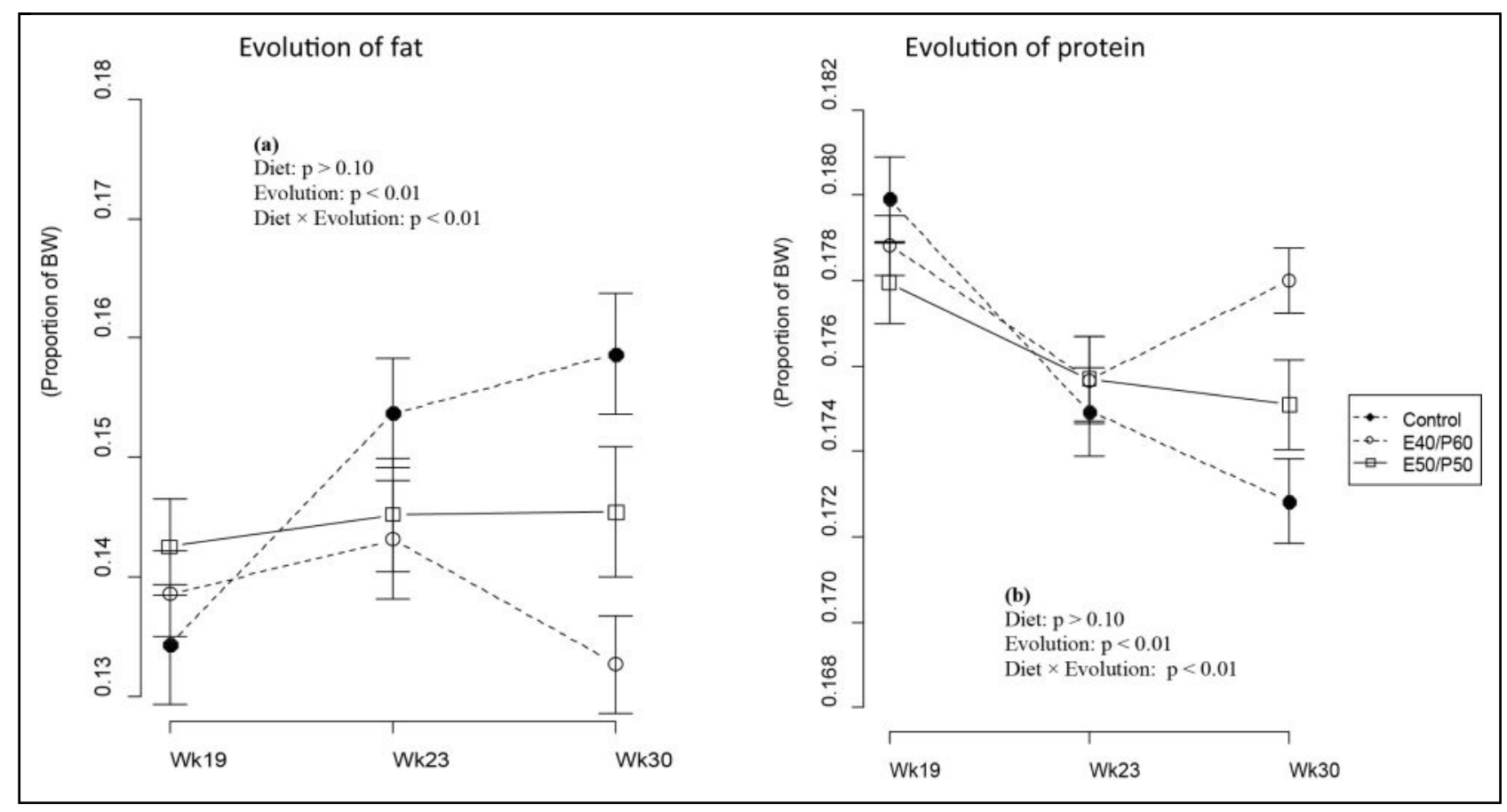

Figure 2. Effects of feeding systems between week 20 and 23 of life on estimated body composition (protein proportion and fatproportion) at 19, 23 and 30 weeks-old for laying hens fed with control or a sequential combination of energy and protein fractions between 19 and 30 weeks of age under high temperature (Exp. 2)

Einfluss des Fütterungssystems zwischen der 20. und 23. Lebenswoche auf die geschätzte Körperzusammensetzung (Protein- und Fettanteil) von Legehennen, die zwischen der 19. und 30. Lebenswoche mit einem Kontrollfutterregime oder einer sequentiellen Kombination von Energie- und Proteinfraktionen gefüttert wurden, in der 19., 23. und 30. Lebenswoche unter hohen Umgebungstemperaturen (Versuch 2)

It was pointed out through the results obtained during 20 and 23 weeks-of-age that laying hens subjected to high temperature tended to eat less and produced as well as the control. When hens were offered the same diet in sequential feeding from 24 to 29 weeks, they converged to the same feeding characteristics at week 30. 


\section{Discussion}

Effect of the feeding systems in the neutral temperature room (Exp. 1)

The chosen unbalance between energy and protein within each fraction and the sequential supply should help to monitor body weight and composition at 30 weeks of age. Regarding feed intake, the aim was reached since hens in sequential feeding had a daily morning fraction offer that drove the expected $40 \%, 50 \%$ and $60 \%$ intakes of the daily supply in the first period. Distribution of high-energy fraction followed by a protein-mineral one has improved feed efficiency for sequential diets compared to the control one in the first period. This improvement might be due to a slight under-consumption of feed and a higher egg production for sequentially fed hens compared to control ones as observed previously (UMAR FARUK et al., 2010a, b, 2011; TRAINEAU et al., 2013). This efficiency may also result of a more efficient digestion thanks to the fractional distribution (CHAGNEAU et al., 2009).

Besides, during the unbalanced period, similar ME and CP intakes were observed comparing control to sequential diets, suggesting a regulation of these nutrients by sequentially fed birds, consistently with BLAIR et al. (1973), MACISAAC and ANDERSON (2007) and UMAR FARUK et al. (2010b). Hens could fit their feed intake to satisfy their energy requirements; then, an increase in energy concentration leading to a reduced feed intake (PEREZ-BONILLA et al., 2012) while increasing dietary protein could increase (GUNAWARDANA et al., 2008) or have no effect (SUMMERS and LEESON, 1994; MOHITI-ASLI et al., 2012) on feed intake. In the second period, all hens were offered $50 \% \mathrm{E}$ and $50 \%$ P. ME intake tended to be lower for sequential diets compared to the control one. Moreover, hens in sequential feeding were thinner and had lower abdominal fat weight than those in control continuous diet. As demonstrated by SMITH (1973), higher energy consumption than it is required for maintenance and production led to fat deposition, increasing the body weight as observed here with the difference in body weight and fat content between sequential and control fed birds.

Focusing on sequential diets, differences in CP intake could be observed in the unbalanced period while no difference in ME intake was observed. Two hypotheses could be proposed. First of all, the composition of the offered diets (BOUVAREL et al., 2004) leading to contrasted nutrient intake: the gap between $\mathrm{E}$ offered in the morning and $\mathrm{P}$ distributed in the afternoon is more pronounced in crude protein $(98.0 \mathrm{~g} / \mathrm{kg}$ for E vs. $231.7 \mathrm{~g} / \mathrm{kg}$ for $\mathrm{P}$; $59 \%$ of difference) than in metabolizable energy (13.1 MJ/kg for E vs. $8.8 \mathrm{MJ} / \mathrm{kg}$ for P; $37.3 \%$ of difference). With the same amount of feed, energy and protein unbalance are not symmetrical which could induce a lack in other nutrients such as amino acids. Regarding two limiting amino acids, methionine and lysine (NOVAK et al., 2004; MOGHADDAM et al., 2012), hens in sequential diets did not present any differences in total lysine and methionine intakes compared to the control diet but within the sequential group, there was a difference $(\mathrm{P}<0.01)$ in these intakes. As demonstrated by HARMS and RUSSELL (1998), KESHAVARZ (2003) and MOGHADDAM et al. (2012), simultaneous reduction of dietary protein, methionine and lysine could reduce laying performances. Consistently, increasing methionine level significantly increased laying performances (SAKI et al., 2012) up to an asymptotic level between $0.36-0.38 \%$ (BOUVAREL et al., 2010).It seems therefore that hens are notable to finely tune their feed intake on the proportion of protein in the diet as observed by MOHITI-ASLI et al. (2012) but they are able to adapt their feed intake to the energy in the diet, even though deviations could be observed (BOUVAREL et al., 2010).

\section{Effect of feeding systems and high temperature on laying hens performances (Exp. 2)}

The aim of this experiment was to determine if high environmental temperature was affecting birds' performances offered sequential diets. Birds sequentially fed met the expected consumptions of $\mathrm{E}$ and $\mathrm{P}$ with the same hierarchy. This feed intake behavior could be explained by the reduction in appetite when the temperature is above $21^{\circ} \mathrm{C}$ (SMITH, 1973; MASHALY et al., 2004). Indeed, at high temperature, bird regulates its heat production by decreasing global feed intake or specific nutrient yielding heat during processing (SYAFWAN et al., 2012) which is consistent with our data of a lower E intake for sequentially fed birds compared to the control diet. Furthermore, the ingestion of excess carbohydrate produces a heat increment equivalent to $10-15 \%$ of the metabolizable energy while fat may produce 0 $-5 \%$ (KLEYN, 2013). Since E is higher in calculated fat content than P (46.8 g/ $\mathrm{kg}$ vs. $34.5 \mathrm{~g} / \mathrm{kg}$, respectively), this might also contribute to explain the lower E intake under high temperature. Thus, UMAR FARUK et al. (2010a) hypothesized that the reduced total feed intake in sequential feeding under hot climate, combined with similar performance to conventional feeding, could lead to an improved feed utilization. Moreover, FCR in sequential diets were lower during the first period than in the second one while, according to the rearing guidelines, FCR decreased with age and temperature (PEGURI and COON, 1991) and is higher at the onset as observed in neutral temperature. 
Our results stressed that there was a reduction in body weight and body weight gain due to treatments: birds fed sequentially had lower body weight compared to conventional feeding as observed in neutral temperature room (SMITH, 1973; UMAR FARUK et al., 2010a). Moreover, as it was hypothesized in neutral temperature condition, sequentially fed birds seem to have a lower fat deposition according to lower maintenance requirements (UMAR FARUK et al., 2010a). This metabolic mechanism might be similar in high temperature room since their energy requirements for maintenance decreased with temperature (DAGHIR, 2008). According to PEGURI and COON (1991) and CHENG et al. (1997), hot ambient temperatures lead to a decreased growth performance of birds due to a restriction in nutrients intakes and physiological changes observed in hot environment (CHENG et al., 1997; MUJAHID, 2011).

\section{Conclusions}

These studies indicate that laying hens in sequential feeding were able to modify their feed intake when diets varied in energy and protein contents. However, they highlighted the difficulty to increase robustness of animals by controlling weight gain. It would be interesting in future work to successfully control the performances of sequentially fed birds throughout the laying period according to their growth performances.

Moreover, these works suggest that high environmental temperature does not disable sequential feeding benefits. Previous studies have shown that hens supplied with sequential diet, could be more fragile, which was here observed through a decrease of performances with temperature. It must therefore be ensured, that hens fed sequentially, under high temperatures, will not be too thin or deficient in specific nutrient, in order to last a complete commercial laying period. There is however the need to investigate laying hens' responses to amino acids imbalance. Indeed, during the first period, temperature did not affect lysine and methionine intakes while there was a feeding system effect according to the diets offered. During the second period, there was a reduction in these two limiting amino acids intakes, suggesting that the length of exposure to heat may affect the response of birds as observed for protein (GONZALEZ-ESQUERRA and LEESON, 2005). Exposure to high temperature has been shown to influence amino acids digestibility (WALLIS and BALNAVE, 1984; BRAKE, 1998; MUJAHID, 2011). Attention should be given to an imbalance that was potentially induced by sequential feeding of diets varying both in energy and protein content.

\section{Acknowledgments}

We thank Philippe Didier and Michel Couty (INRA) for their technical assistance. We are grateful to our experimental unit (UE PEAT) for its help in the set-up of the experiment. The scientific and financial support of INZO (Montgermont, France) and the financial help of the French Embassy in Benin are highly appreciated.

\section{Summary}

Sequential feeding consists in splitting the diet into two fractions. Distribution of a high-energy diet in the morning followed by a diet rich in protein and calcium in the afternoon, can significantly improve feed efficiency. Nevertheless, previous works showed the difficulty of hens to regulate their feed intake and to overcome high temperatures when fed sequentially. Two experiments have been conducted to understand whether, controlling laying hens' feed consumption in sequential feeding system, would drive them to an optimal body weight and body composition. Feed consumption and performances of birds offered sequential diets unbalanced in energy and protein contents were investigated under two contrasted temperatures from 20 to 30 weeks of age. A complete diet was fed as control and given in equal portions twice a day. Birds in sequential diets received the high-energy fraction (E) in the morning and beginning of the afternoon and the high protein and mineral fraction (P) in the late afternoon and early morning.

Four different diets were provided between 20 and 23 weeks old for birds in experiment 1 (Exp. 1): control diet and 3 sequential diets $(40 \% \mathrm{E} / 60 \% \mathrm{P} ; 50 \% \mathrm{E} / 50 \% \mathrm{P} ; 60 \% \mathrm{E} / 40 \% \mathrm{P})$. For birds in high temperature condition in the experiment 2 (Exp. 2), 3 diets were given: control diet, 2 sequential diets $(40 \% \mathrm{E} / 60 \% \mathrm{P} ; 50 \% \mathrm{E} / 50 \% \mathrm{P})$. To test the flexibility of birds to converge to the same characteristics at week 30, birds in control group received the same diet and all other birds, the $50 \% \mathrm{E} / 50 \% \mathrm{P}$ one from 24 to 29 weeks.

The results showed that under neutral temperature (Exp. 1), hens in sequential groups were different to the control one between 20 to 23 weeks, regarding feed efficiency. From 24 to 29 weeks, birds with different feed supply at 23 
week converged to the same consumption. Laying performances and body composition did not vary in the sequential groups with the change of diets. Since birds fed sequentially in experiment 2 (Exp. 2) tended to consume less and produced as well as control fed birds, it might be concluded that high environmental condition reduced bird's performances but did not hide the effects of sequential feeding system.

\section{Key words}

Laying hens, sequential feeding, unbalanced diets, temperature, feed intake, performance

\section{Zusammenfassung}

Vermögen von Legehennen, die zuvor mit einer unausgewogenen Ration gefüttert wurden, die Futteraufnahme bei sequentieller Fütterung optimal einzustellen

Bei der sequentiellen Fütterung wird die Tagesration in zwei unterschiedlichen Fraktionen gefüttert. So, wird z.B. vormittags eine Ration mit hohem Energiegehalt und nachmittags eine Protein- und Kalzium-reiche Ration angeboten. Es hat sich gezeigt, dass hierdurch die Futterverwertung signifikant verbessert werden kann. Allerdings wurde in früheren Versuchen festgestellt, dass die Hennen bei hohen Umgebungstemperaturen Probleme haben, ihre Futteraufnahme richtig zu steuern. Das Ziel der zwei durchgeführten Versuche war daher, zu prüfen, ob über eine Kontrolle der Futteraufnahme bei der sequentiellen Fütterung eine Optimierung des Körpergewichts und der Körperzusammensetzung erreicht werden kann. Hierzu wurden die Futteraufnahme und die Leistung von Legehennen, die im Alter von 20 bis 30 Lebenswochen bei zwei sehr unterschiedlichen Umgebungstemperaturen gehalten wurden und in dieser Zeit zwei im Hinblick auf den Energie- und Proteingehalt unbalanzierte Rationen erhielten, erfasst. In der Kontrollgruppe wurden die Hennen zweimal am Tag mit einer vollständigen Futterration gefüttert. Die Hennen der Behandlungsgruppe erhielten die Energie-reiche Ration E am Morgen und am frühen Nachmittag, während die Protein-reiche Ration (P) am späten Nachmittag und am frühen Morgen angeboten wurden. Im ersten Versuchsdurchgang wurden vier Versuchsrationen zwischen der 20. und 23. Lebenswoche gefüttert: Kontrolle und 3 sequentielle Rationen (40\% E/60\% P; 50\% E/50\% P; 60\% E/40\% P). Im zweiten Versuchsdurchgang mit erhöhter Umgebungstemperatur kamen drei Rationen zum Einsatz: Kontrolle und 2 sequentielle Rationen (40\% E/60\% P; 50\% E/50\% P). Die Flexibilität der Hennen wurde getestet, indem die Hennen nach der Testphase (20.-23. Lebenswoche) bis zur 29. Lebenswoche mit einer 50\% E/50\% P-Ration gefüttert wurden. Die Leistungsparameter wurden dann in der 30. LW ermittelt.

Unter normalen Temperaturbedingungen (Versuch 1) unterschied sich die Futterverwertung der sequentiell gefütterten Hennen zwischen der 20. und 23. Lebenswoche von der der Kontrollgruppe. Zwischen der 24 . und 29. Lebenswoche näherte sich die Futteraufnahme der vorher sequentiell gefütterten Hennen an die der Kontrolle an. Die Legeleistung und die Körperzusammensetzung der sequentiell gefütterten Hennen veränderte sich mit dem Wechsel der Rationen nicht. Nachdem die sequentiell gefütterten Hennen in Versuch 2 ähnliche Leistungen bei tendenziell geringerer Futteraufnahme erreichten wie die Kontrolltiere, kann daraus der Schluss gezogen werden, dass hohe Umgebungstemperaturen zwar zu einer Leistungsreduzierung führen, aber die Effekte der sequentiellen Fütterung sichtbar bleiben.

\section{Stichworte}

Legehenne, sequentielle Fütterung, unausgewogene Ration, Temperatur, Futteraufnahme, Leistung

\section{References}

AlmeidA, V.R., A.N. DiAs, C.F.D. Bueno, F.A.P. Couto, P.A. Rodrigues, W.C.L. NogueirA, D.E. FARIA Filho, 2012: Crude protein and metabolizable energy levels for layers reared in hot climates. Braz. J. Poult. Sci. 14, 203-208.

ARIMA, Y., F.B. MATHER, M.M. AHMAD, 1976: Response of egg-production and shell quality to increases in environmental-temperature in 2 age-groups of hens. Poult. Sci. 55, 818-820.

BALNAVE, D., J. BRAKE, 2005: Nutrition and management of heat-stressed pullets and laying hens. World's Poult. Sci. J. 61, 399-406. 
BERG, E.P., M.J. MARCHELLO, 1994: Bioelectrical-Impedance analysis for the prediction of fat-free mass in lambs and lamb carcasses. J. of Anim. Sci. 72, 322-329.

BLAIR, R., W.A. DEWAR, J.N. DOWNIE, 1973: Egg production responses of hens given a complete mash or unground grain together with concentrate pellets. Br. Poult. Sci. 14, 373-377.

Bouvarel, I., B. BARrier-Guillot, P. LARroude, B. Boutten, C. Leterrier, F. Merlet, M. Vilarino, L. RofFidAL, S. Tesseraud, J. CASTAING, M. PICARD, 2004: Sequential feeding programs for broiler chickens: Twenty-four- and forty-eight-hour cycles. Poult. Sci. 83, 49-60.

Bouvarel, I., Y. NYS, M. PANHELEuX, P. LeSCOAT, 2010: How hen's diet influences egg quality? INRA Prod. Anim. 23 (2), 167-182.

BRAKE, J., 1998: Optimum dietary arginine: Lysine ratio for broiler chickens is altered during heat stress in association with changes in intestinal uptake and dietary sodium chloride. Br. Poult. Sci. 39(5), 639-647.

CANET, Z.E., B.M. Romera, V. FAin BindA, A. Terzaghi, A.M. DotTAVio, R.J.D. MAsso, 2012: Productive indicators at sexual maturity in experimental populations of free range layers. Rev. Argent. Prod. Anim. 32, 37-46.

Chagneau, A.M., S. Lecuelle, P. Lescoat, M. Quentin, J.M. Guillaumin, I. Bouvarel, 2009: The slow growing chicken well add value food distribution by meal. $8{ }^{\text {èmes }}$ Journées de la recherche avicole, St Malo, France, 25-26 March 2009, p. 59.

CHENG, T.K., M.L. HAMRE, C.N. COON, 1997: Effect of environmental temperature, dietary protein, and energy levels on broiler performance. J. Appl. Poult. Res. 6, 1-17.

DAGHIR, N.J., 2008: Nutrient requirements of poultry at high temperatures, in: N.J. DAGHIR (Eds) Poultry production in hot climates, $2^{\text {nd }}$ ed, pp. 132-159 (UK, Cromwell Press).

DANIEL, M., D. BALNAVE, 1981: Responses of laying hens to gradual and abrupt increases in ambient-temperature and humidity. Austr. J. Exp. Agric. 21, 189-195.

DEATON, J.W., F.N. REECE, B.D. LOTT, 1986: Effect of summer cyclic temperatures versus moderate temperature on laying hen performance. Poult. Sci. 65, 1649-1651.

EMERY, D.A., P. VOHRA, R.A. ERNST, S.R. MORRISON, 1984: The effect of cyclic and constant ambient-temperatures on feed consumption, egg-production, egg weight, and shell thickness of hens. Poult. Sci. 63, 2027-2035.

GONZALEZ-ESQUERRA, R., S. LEESON, 2005: Effects of acute versus chronic heat stress on broiler response to dietary protein. Poult. Sci. 84, 1562-1569.

GunawardanA, P., D.A. Roland, M.M. Bryant, 2008: Effect of Energy and Protein on Performance, Egg Components, Egg Solids, Egg Quality, and Profits in Molted Hy-Line W-36 Hens. J. Appl. Poult. Res. 17, $432-439$.

HARMS, R.H., G.B. RUSSELL, 1998: Layer performance when returned to a practical diet after receiving an amino aciddeficient diet. J. Appl. Poult. Res. 7, 175-179.

ISA, 2011: Nutrition Management Guide, 2011 Edition. ISA Hendrix Genetics, Saint Brieuc, France.

KESHAVARZ, K., 1998: Further investigations on the effect of dietary manipulation of protein, phosphorus, and calcium for reducing their daily requirement for laying hens. Poult. Sci, 77: 1333-1346.

KESHAVARZ, K., 2003: Effects of reducing dietary protein, methionine, choline, folic acid, and vitamin B-12 during the late stages of the egg production cycle on performance and eggshell quality. Poult. Sci. 82, 1407-1414.

KLEYN, R., 2013: Chicken nutrition. A guide for nutritionists and poultry professionals. ISBN: 978-1-899043-42-2, 347 pages, Context 2013.

LEE, K.H., Y.S. OHH, 2002: Effects of nutrient levels and feeding regimen of a.m. and p.m. diets on laying hen performances and feed cost. Kor. J. Poult. Sci. 29, 195-204.

LEESON, S., J.D. SUMMERS, 1978: Voluntary food restriction by laying hens mediated through dietary self-selection. Br. Poult. Sci. 19, 417-424. 
MACISAAC, J.L., D.M. ANDERSON, 2007: Effect of whole wheat, enzyme supplementation and grain texture on the production performance of laying hens. Can. J. Anim. Sci. 87, 579-589.

Mashaly, M.M., G.L. Hendricks, M.A. Kalama, A.E. GeHAD, H. PATTERSON, A.O. AbBAS, 2004: Effect of Heat Stress on Production Parameters and Immune Responses of Commercial Laying Hens. Poult. Sci. 83, 889-894.

Moghaddam, H.N., M.K. FARD, M.J. AgAH, S.J. Hosseini, M.T. MiraKZEHI, 2012: Effect of different levels of methionine, protein and tallow on the productive performance and egg quality of laying hens in the late-phase production. Braz. J. Poult. Sci. 14, 149-158.

Mohiti-Asli, M., M. Shivazad, M. Zaghari, M. RezAiAn, S. AminZAdeH, G.G. MATEOS, 2012: Effects of feeding regimen, fiber inclusion, and crude protein content of the diet on performance and egg quality and hatchability of eggs of broiler breeder hens. Poult. Sci. 91, 3097-3106.

MUJAHID, A., 2011: Nutritional strategies to maintain efficiency and production of chickens under high environmental temperature. J. Poult. Sci. 48, 145-154.

NIR, I., J.P. MELCION, M. PICARD, 1990: Effect of particle-size of sorghum grains on feed-intake and performance of young broilers. Poult. Sci. 69, 2177-2184.

NovaK, C., H. YAKOUT, S. SCHEIDELER, 2004: The combined effects of dietary lysine and total sulfur amino acid level on egg production parameters and egg components in Dekalb Delta laying hens. Poult. Sci. 83, 977-984.

PEgURI, A., C. CoON, 1991: Effect of temperature and dietary energy on layer performance. Poult. Sci. 70, $126-138$.

Perez-Bonilla, A., S. NovoA, J. Garcia, M. Mohiti-Asli, M. FriKhA, G.G. MAteOS, 2012: Effects of energy concentration of the diet on productive performance and egg quality of brown egg-laying hens differing in initial body weight. Poult. Sci. 91, 3156-3166.

REICHMANN, K.G., J.K. CONNOR, 1979: Effects of meal feeding of calcium, protein and energy on production and calcium status of laying hens. Br. Poult. Sci. 20, 445-452.

RCORE TEAM, 2012: R: A Language and Environment for Statistical Computing. R Foundation for Statistical Computing.

ROBINSON, D., 1985: Performance of laying hens as affected by split time and split composition dietary regimens using ground and unground cereals. Br. Poult. Sci. 26, 299-309.

RutTer, K., L. Hennoste, L.C. WARD, B.H. CORniSH, B.J. ThOMAS, 1998: Bioelectrical impedance analysis for the estimation of body composition in rats. Lab. Anim. 32, 65-71.

SAKI, A.A., R.N. HARsini, M.M. TABAtAbaei, P. ZAMANI, M. HAghight, 2012: Estimates of methionine and sulfur amino acid requirements for laying hens using different models. Braz. J. Poult. Sci. 14, 209-216.

SAUVAnt, D., J.-M. Perez, G. TRAN, 2004: Tables of composition and nutritional value of feed materials, INRA Editions and AFZ. Wageningen Academic Publishers, Paris, France.

SCANES, C.G., R. CAMPBELL, P. GRIMINGER, 1987: Control of energy-balance during egg-production in the laying hen. J. Nut. 117, 605-611.

SMITH, A.J., 1973: Some effects of high environmental temperatures on the productivity of laying hens (a review). Trop. Anim. Health Prod. 5, 259-271.

SUMMERS, J.D., S. LEESON, 1994: Laying hen performance as influenced by protein intake to sixteen weeks of age and body weight at point of lay. Poult. Sci. 73, 495-501.

SYAFWAN, S., G.J.D. WERMINK, R.P. KWAKKEL, M.W.A. VERSTEGEN, 2012: Dietary self-selection by broilers at normal and high temperature changes feed intake behavior, nutrient intake, and performance. Poult. Sci. 91, 537-549.

Traineau, M., I. Bouvarel, C. Mulsant, L. Roffidal, C. Launay, P. LescoAt, 2013: Effects on performance of ground wheat and with or without insoluble fiber or whole wheat in sequential feeding for laying hens. Poult. Sci. 92, 2475-2486. 
UMAR FARUK, M., E. DEZAT, I. BOUVAREL, Y. NYS, P. LESCOAT, 2008: Loose-mix and sequential feeding of mash diets with whole-wheat: effect on feed intake in laying hens. Proceedings of the XXIII ${ }^{\text {th }}$ World's Poultry Congress, Brisbane, Australia. p. 468.

UMAR FARUK, M., 2010: L'évaluation de l'alimentation mélangée et séquentielle à base de matières premières localement disponibles sur les performances des poules pondeuses en France et au Nigéria. Ph. D. Thesis, Université François-Rabelais de Tours.

Umar Faruk, M., I. Bouvarel, N. Meme, N. RideAu, L. Roffidal, H.M. TUkUR, D. BASTIANElli, Y. Nys, P. LescoAt, 2010a: Sequential feeding using whole wheat and a separate protein-mineral concentrate improved feed efficiency in laying hens. Poult. Sci. 89, 785-796.

UMAR FARUK, M., I. BOUVAREL, N. MÊME, L. RoffidAl, H.M. TUKUR, Y. NYS, P. LeSCOAT, 2010b: Adaptation of wheat and protein-mineral concentrate intakes by individual hens fed ad libitum in sequential or in loose-mix systems. Br. Poult. Sci. 51, 811-820.

UMAR FARUK, M., I. BOUVAREL, S. MALlet, M.N. Ali, H.M. TUKUR, Y. NyS, P. LeSCOAT, 2011: Is sequential feeding of whole wheat more efficient than ground wheat in laying hens? Anim. 5, 230-238.

WALLIS, I.R., D. BALNAVE, 1984: The influence of environmental-temperature, age and sex on the digestibility of amino-acids in growing broiler-chickens. Br. Poult. Sci. 25, 401-407.

Correspondence: P. Lescoat, AgroParisTech, Département Sciences de la Vie et Santé - UFR Développement des Filières Animales, 16, rue Claude Bernard, 75231 Paris, France; E-mail: philippe.lescoat@agroparistech.fr

\section{Fußnoten:}

INZO SAS rue de l'Eglise-BP 5001902407 Chierry Cedex 